\title{
Volcanic Geoheritage
}

\author{
Károly Németh $^{1} \cdot$ Thomas Casadevall $^{2} \cdot$ Mohammed Rashad Moufti $^{3} \cdot$ Joan Marti $^{4}$
}

Published online: 5 August 2017

(C) The European Association for Conservation of the Geological Heritage 2017

Volcanic landscapes and volcanism together can fascinate a general public about the forces of nature (Fig. 1). Volcanism has produced devastating natural disasters through human history but has also fostered the course of the evolution of humankind and its societies. Numerous volcanic processes are among those that captivate human minds at every level and provide fundamental information for understanding how the Earth works. In recent years, research in general geoheritage has grown. Geological heritage is commonly viewed through micro to macro scales associated with a geological site's significance in relationship to Earth history or to a specific geological process. Over the past decade, numerous methods have been proposed to measure the geoheritage value of a geological (and/or geomorphological) site from various perspectives, commonly centred on their geotouristic, geoconservation or

Károly Németh

k.nemeth@massey.ac.nz

Thomas Casadevall

tcasadevall@usgs.gov

Mohammed Rashad Moufti

mrmoufti@gmail.com

Joan Marti

joan.marti@ictja.csic.es

1 Massey University, Institute of Agriculture and Environment Volcanic Risk Solutions, PO Box 11 222, Palmerston North, New Zealand

2 U.S. Geological Survey, Denver Federal Center, MS 964, P.O. Box 25046, Denver, CO 80225, USA

3 Geohazards Research Centre, King Abdulaziz University, Jeddah, Kingdom of Saudi Arabia

4 Institute of Earth Sciences "Jaume Almera”, CSIC, Lluis Sole Sabaris s/n, 08028 Barcelona, Spain geoeducation values. This definition of geoheritage is largely westernized and recent researches show clearly that indigenous knowledge needs to be factored into evaluating the geoheritage values of geosites.

Commonly, geoheritage evaluation emphasizes the significance of the geodiversity. Definitions currently embraced by the term geodiversity include the variety of rocks, minerals, fossils, landforms, sediments, water and soils, together with the natural processes which form and alter them. Geoheritage comprises those elements of the Earth's geodiversity that are considered to have significant scientific, educational, cultural or aesthetic value. Geoconservation refers to the actions and measures taken to conserve geodiversity and geoheritage for the future (Gray 2013). The story of the Earth is one of the main aspects of geoheritage, and it is commonly reflected in its geodiversity. In this sense, geoheritage is the link between natural phenomena and the human understanding of how the Earth works (Cook and Abbott 2015).

Within this framework, volcanic geoheritage represents the fascinating processes of volcanism that have equally frightened, destroyed and provided materials and a 'geoenvironment' to allow our human society to flourish (Erfurt-Cooper 2011). Volcanism has a particularly high interest to the general public due to the human-scale time frame of its actions and the very graphic consequences of both destructive and productive aspects. As a result, geoparks with active volcanoes and in areas dominated by recent volcanism are growing in popularity (Joyce 2009, 2010a, b; Kazanc1 2012; Migon and Pijet-Migon 2016a). Several new studies have even express the overlooked opportunities that volcanic geological sites can provide for facilitating geotourism in regions not directly associated with active volcanism (Migon and Pijet-Migon 2016b). These recent developments undeniably provide significant added values to the geotouristic, geoeducation and geoconservation programs of recently 


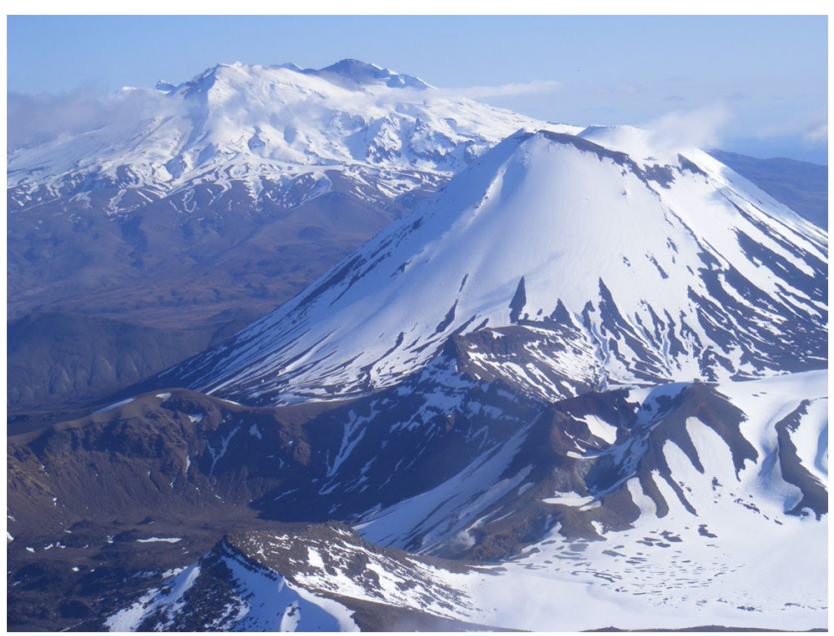

Fig. 1 UNESCO World Heritage Site-Tongariro National Park, New Zealand is the home of iconic and well-researched active quaternary volcanoes such as the Mount Ngauruhoe (snow-capped cone in the middle) and Ruapehu (in the background). Tongariro's dual World Heritage status recognises the Park's important Maori cultural and spiritual associations as well as its outstanding volcanic features

established Geoparks, many of them reaching UNESCO Global Geopark status (for instance the Bakony-Balaton UNESCO Global Geopark in Hungary (http://www.geopark. hu/en/; Csillag et al. 2004; Szepesi et al. 2017)).

Several volcanic regions located in inactive volcanic areas are the type localities of special type of volcanism such as those in the Eifel in western Germany. These areas provide exceptionally good educational avenues for the dissemination of our current understanding on specific types of volcanism (Bitschene and Schueller 2011; Bitschene 2015). Volcanic landscapes are also among some of the most distinctive protected areas of the World Heritage Program, the Global Geopark Network and the Man in the Biosphere programs. These landscapes are identified for their biological, geological and cultural values to communities and societies across the globe.

Despite global recognition for volcanic landscapes, important questions, however, remain. Are the world's most significant and important volcanic landscapes recognized and properly protected? What are the challenges in the management of volcanic world heritage properties in the future? Are the various regions of the globe properly represented in these programs? To address these questions, the International Union for the Conservation of Nature (IUCN) has undertaken a revision of its previously published work, the Volcano Thematic Study on World Heritage Volcanoes, which focused solely on World Heritage properties (Wood 2009). This revision examines not only World Heritage properties but also includes properties currently in the Man in the Biosphere Programme, as well as in the Global Geopark Network. Preliminary evaluation of the current lists of properties show that for World Heritage sites, 58 of $1031(5.8 \%)$ have significant volcanic features; for
Biosphere Reserves, 57 of 651 (8.7\%) have significant volcanic features; and for Global Geoparks, 21 of $120(17.5 \%)$ have significant volcanic features.

All these developments have recently gained the attention of the International Association of Volcanology and Chemistry of the Earth's Interior (IAVCEI) with the establishment of the Commission on Volcanic Geoheritage and Protected Volcanic Landscapes. (https://vhub.org/groups/ iavcei_vgpl). The new IAVCEI commission can act as a "knowledge hub" and provide quality control for "the design of scientifically correct geoconservation, geoeducation and geotouristic programs' (Showstack 2015). The Commission also aims intend to ensure stronger IAVCEI representation in various geoprotection programs (Showstack 2015).

Thanks to the general interest on volcanism in a geotourisitic approach some fundamental summary of studies have recently appeared, promoting volcanic geoheritage research and generating a growing interest in the subject both from both tourism research and volcanic research aspects (Erfurt-Cooper 2014; Errami et al. 2015; Martí and Planagumà 2017; Moufti and Németh 2016; Woo et al. 2013).

Geoheritage research studies are numerous as represented by a survey on Web of Science searching topics on 'geoheritage' that provided 283 scores in June 2017 with the earliest listed paper from the year 2000. In the same time, also using Web of Science, the 'volcanic geoheritage' keyword hit 25 papers. Among these publications, the earliest, however, was published only in 2010. This indicates that this research subject in the mainstream scientific media is new, but promising to grow in the near future as more volcano scientists see the opportunity to use volcanic geoheritage research for knowledge transfer of volcanism and volcanic hazard, especially in those regions located in active volcanic regions. Crucially, volcanic geoheritage is increasingly being seen as a potential avenue for the dissemination of information on volcanism and volcanic hazards.

This special issue is a direct result of the activity of the new IAVCEI commission. In the past 2 years, special conferences on volcanic geoheritage and special sessions during major scientific conferences have been held, generating a great interest from the specialist community. Among these meetings, the VOLCANDPARK conferences have been very successful. VOLCANDPARK is the international congress programme devoted to the management, the raising of awareness and geotourism in protected volcanic areas. It aims to provide a unique opportunity to bring together people from many different fields (scientists, administrators, politicians, tour operators, etc.), any of whom may become involved in some way in territorial planning, management and promotion of protected volcanic areas (national and natural parks, natural reserves, etc.). The first VOLCANDPARK took place in 2012 in Olot (Spain), in La Garrotxa Volcanic Zone 
Natural Park, whilst the second VOLCANDPARK was held in Lanzarote, Canary Islands, Spain (16-20 November 2015).

This current Special Issue of Geoheritage provides a snapshot of the current state of researches associated with volcanic geoheritage. It does not provide a full picture of the subject, but does provide an overview of the main research themes associated with this subject. The volume also provides a representative selection of papers from the research associated with the utilisation of indigenous knowledge of volcanic geoheritage values to develop a more balanced approach for geosite evaluation as well as the incorporation of information relevant to geotoursitic and/or land use purposes (Fepuleai et al. 2017; Gravis et al. 2017). Also included are reports from regions with a high volcanic geodiversity that is underutilized both from geotoursitic and geohazard education perspectives, but could be developed into major regional or even global hubs for such knowledge (Németh and Moufti 2017; Németh et al. 2017; Žáček et al. 2017; Zangmo et al. 2017). Similarly, other studies demonstrates the potential of other volcanic geoheritage sites to be utilized for geoeducation and geoconservation, as well as for their geotouristic potential (Alessio 2017; Sheth et al. 2017; Szakacs 2017; Szepesi et al. 2017). Other papers presented consider the potential of using modern technologies (Rapprich et al. 2017) or innovative approaches to disseminate an understanding of volcanic geology processes (Szepesi et al. 2017).

In conclusion, we offer this volume as the first major output of the new IAVCEI commission and hope that this Special Issue of Geoheritage will generate interest within the volcanic and geoheritage community. Crucially, it is hoped that it will encourage these communities to explore opportunities to use their research results to develop effective modern approaches for the dissemination of information about volcanism, volcanic hazard, volcanic geoheritage and geotourism.

\section{References}

Alessio G (2017) Promotion and development of protected volcanic areas through field-based environmental communication activities. The 'Gran Cono' tour in the Vesuvius National Park (Italy). Geoheritage this volume

Bitschene P, Schueller A (2011) Geo-education and geopark implementation in the Vulkaneifel European Geopark. GSA Field Guide 22: 29-34

Bitschene PR (2015) Edutainment with basalt and volcanoes-the Rockeskyller Kopf example in the Westeifel volcanic field/ Vulkaneifel European Geopark, Germany. Zeitschrift Der Deutschen Gesellschaft Fur Geowissenschaften 166(2):187-193

Cook T, Abbott L (2015) Geoheritage: Preserving the Earth's Legacy: EARTH https://www.earthmagazine.org/article/geoheritagepreserving-earths-legacy

Csillag G, Korbely B, Németh K (2004) Volcanological sites of Balaton uplands National Park as key points for a proposed geopark in western Hungary. Occasional Papers of the Geological Institute of Hungary 203:49-49

Erfurt-Cooper P (2011) Geotourism in volcanic and geothermal environments: playing with fire? Geoheritage 3(3):187-193

Erfurt-Cooper P (2014) Volcanic tourist destinations. In: Eder W, Bobrowsky PT, Martínez-Frías J (eds) Geoheritage. Geoparks and Geotourism, Springer, Heidelberg, p 384

Errami E, Brocx M, Semeniuk V (2015) From Geoheritage to Geoparks: case studies from Africa and beyond. In: Eder W, Bobrowsky PT, Martínez-Frías J (eds) Geoheritage. Geoparks and Geotourism, Springer, Heidelberg, p 269

Fepuleai A, Weber E, Németh K, Muliaina T, Iese V (2017) Eruption styles of Samoan volcanoes represented in tattooing, language and cultural activities of the indigenous people. Geoheritage this volume

Gravis I, Németh K, Procter JN (2017) The role of cultural and indigenous values in geosite evaluations on a quaternary monogenetic volcanic landscape at Ihumātao, Auckland volcanic field, New Zealand. Geoheritage this volume

Gray M (2013) Geodiversity, Wiley Blackwell, ISBN: 978-0-470-74215$0,508 \mathrm{p}$

Joyce B (2009) Geomorphosites and volcanism. In: Reynard E, Coratz P, Regolini-Bissing G (eds) Geomorphosites. Verlag Dr. Friedrich Pfeil, München, Germany, pp 175-188

Joyce B (2010a) Volcano tourism in the new Kanawinka global Geopark of Victoria and SE South Australia. In: Erfurt-Cooper P, Cooper M (eds) Volcano and geothermal tourism. Sustainable Geo-Resources for Leisure and Recreation. Earthscan, London, UK, pp 302-311

Joyce E (2010b) Australia's geoheritage: history of study, a new inventory of geosites and applications to geotourism and geoparks. Geoheritage 2(1-2):39-56

Kazanc1 N (2012) Geological background and three vulnerable geosites of the Kızılcahamam-Camlıdere geopark project in Ankara, Turkey. Geoheritage 4(4):249-261

Martí J, Planagumà L (2017) La Garrotxa volcanic field of Northeast Spain. In: Eder W, Bobrowsky PT, Martínez-Frías J (eds) Geoheritage. Geoparks and Geotourism, Springer, Heidelberg, p 136

Migon P, Pijet-Migon E (2016a) Geoconservation and tourism at geothermal sites-lessons learnt from the Taupo volcanic zone, New Zealand. Proc Geol Assoc 127(3):413-421

Migon P, Pijet-Migon E (2016b) Overlooked geomorphological component of volcanic geoheritage-diversity and perspectives for tourism industry, Pogrze Kaczawskie region, SW Poland. Geoheritage 8(4): 333-350

Moufti MR, Németh K (2016) Geoheritage of volcanic Harrats in Saudi Arabia. Springer, Heidelberg, pp 1-194

Németh K, Moufti MR (2017) Geoheritage values of a mature monogenetic volcanic field in intra-continental settings: Harrat Khaybar, Kingdom of Saudi Arabia. Geoheritage this volume

Németh K, Wu J, Sun C, Liu J (2017) Update on the volcanic geoheritage values of the Pliocene to quaternary Arxan-Chaihe volcanic field, Inner Mongolia, China. Geoheritage this volume

Rapprich V, Lisec M, Fiferna P, Závada P (2017) Application of modern technologies in popularization of the Czech volcanic geoheritage. Geoheritage this volume

Sheth H, Samant H, Patel V, D'Souza J (2017) The volcanic geoheritage of the Elephanta caves, Deccan traps, western India. Geoheritage this volume

Showstack R (2015) New commission aims to protect volcanic geoheritage. EOS 96(doi:10.1029/2015EO032343)

Szakacs A (2017) Protected natural values of geoheritage interest in the Călimani National Park, eastern Carpathians, Romania. Geoheritage this volume

Szepesi J, Harangi S, Ésik Z, Novák TJ (2017) Volcanic geoheritage and geotourism perspectives in Hungary: a case of an UNESCO world 
heritage site, Tokaj wine region historic cultural landscape, Hungary. Geoheritage this volume

Woo KS, Sohn YK, Yoon S-H, Ahn US, Spate A (2013) Jeju Island Geopark - a volcanic wonder of Korea. Springer, Heidelberg, p 88

Wood (2009) World heritage volcanoes. IUCN, Gland, Switzerland, 70pp

Žáček V, Hradecký P, Kycl P, Ševčík J, Novotný R (2017) The Somoto grand canyon (Nicaragua) - a volcanic geoheritage site one decade after discovery: from field geological mapping to the promotion of a geopark. Geoheritage this volume

Zangmo GT, Kagou AD, Nkouathio DG (2017) The volcanic geoheritage of the Mount Bamenda calderas (Cameroon line): assessment for geotouristic and geoeducational purposes. Geoheritage this volume 